\title{
Effect of Heat-Treatment on Microstructure and Mechanical Behavior of Directionally Solidified Nb-Ti-Si Based Alloy
}

\author{
Yan Junjie, Guo Xiping \\ State Key Laboratory of Solidification Processing, Northwestern Polytechnical University, Xi'an 710072, China
}

\begin{abstract}
With the melting temperature of $2323 \mathrm{~K}$ and withdrawing rate of $100 \mu \mathrm{m} / \mathrm{s}, \mathrm{Nb}-\mathrm{Ti}$-Si based ultrahigh temperature alloy has been directionally solidified with the use of crucibles. The directionally solidified (DS) specimens were subsequently heat-treated in two ways: either at $1723 \mathrm{~K} / 50 \mathrm{~h}$ (HT1) or at $1623 \mathrm{~K} / 50 \mathrm{~h}+1723 \mathrm{~K} / 50 \mathrm{~h}+1373 \mathrm{~K} / 50 \mathrm{~h}$ (HT2). XRD, SEM and EDS have been employed to investigate the influence of heat-treatments on the microstructures and fractography of the directionally solidified alloys. The results show that after heat-treatment, the volume fraction of the large-size primary silicides decreases. Both kinds of heat-treatments could effectively alleviate or even eliminate the segregation in the alloys. The original boundaries between the $(\mathrm{Nb}, X)_{5} \mathrm{Si}_{3}+\mathrm{Nbss}$ eutectic cells in the DS specimens have thoroughly disappeared after heat-treatments. Specifically, silicides have been more evenly distributed after HT2 than HT1. Compared with DS specimens, the average room temperature fracture toughness of the specimens has increased by $12.3 \%\left(19.2 \mathrm{MPa} \cdot \mathrm{m}^{1 / 2}\right)$ while the average tensile strength has increased by $26.6 \%$ and the maximum value reaches $933.2 \mathrm{MPa}$ after HT2. These improvements could be mainly attributed to the more effective dispersion strengthening of $(\mathrm{Nb}, X)_{5} \mathrm{Si}_{3}$ silicide particles and the shape change as well as size increase of the ductile Nbss phases after HT2.
\end{abstract}

Key words: Nb-Ti-Si-based ultrahigh temperature alloy; integrally directional solidification; heat-treatment; fracture toughness; tensile strength

$\mathrm{Nb}$-Ti-Si based ultrahigh temperature alloys have recently received widespread attention and they could be applied at the temperature higher than $1623 \mathrm{~K}$. They are promising for preparing the next generation aero engine blades ${ }^{[1,2]}$ due to their high melting point (over $2023 \mathrm{~K}$ ), moderate density $\left(6.6 \sim 7.2 \mathrm{~g} / \mathrm{cm}^{3}\right)$ and excellent high temperature strength and creep resistance $^{[3,4]}$.

Directional solidification (DS) has been confirmed to be an effective way in optimizing the microstructure ${ }^{[5-7]}$ and improving the mechanical properties ${ }^{[8,9]}$ of $\mathrm{Nb}-\mathrm{Ti}-\mathrm{Si}$ based ultrahigh temperature alloys. The directionally solidified $\mathrm{Nb}$ 22Ti-16Si-6Cr-4Hf-3Al alloys had better room temperature mechanical properties than the as-cast ones ${ }^{[10]}$. Heat treatment could significantly increase the $\mathrm{K}_{\mathrm{Q}}$ values of the arc-melted $\mathrm{Nb}-\mathrm{Si}$ alloys ${ }^{[11]}$. Also, the studies of L. F. Su et al. ${ }^{[12]}$ have proved that the combination of directional solidification and high temperature heat-treatment could greatly increase the room temperature fracture toughness of an $\mathrm{Nb}-\mathrm{Si}$ based alloy. However, the previous studies were only referred to one-step heat-treatment and were more concerned with fracture toughness and compressive properties of the $\mathrm{Nb}-\mathrm{Si}$ based alloys. In fact, the tensile strength of a practical alloy is often more important to evaluate its usability in actual applications.

Considering the status above, in the present paper, a new kind of eutectic $\mathrm{Nb}$-Ti-Si based ultrahigh temperature alloy was designed and prepared in our self-made directional solidification furnace. The influences of two kinds of heattreatments (one-step and three-step) on the microstructure, room temperature fracture toughness and tensile strength of the specimens have been studied and the fracture mechanism has been investigated.

\section{Experiment}

The nominal composition of the Nb-Ti-Si based ultrahigh

Received date: January 14, 2016

Foundation item: National Natural Science Foundation of China (51371145, 51071124); "111" Project (B080401)

Corresponding author: Guo Xiping, Ph. D., Professor, State Key Laboratory of Solidification Processing, Northwestern Polytechnical University, Xi'an 710072, P. R. China, Tel: 0086-29-88494873, E-mail: xpguo@nwpu.edu.cn 
temperature alloy was Nb-20Ti-15Si-5Cr-3Hf-3Al (at\%). Button ingots were firstly prepared by vacuum nonconsumable arc-melting process. To achieve homogeneous distribution of the elements, the button ingots were re-melted and flipped for 5 times. Then the button ingots were re-melted by vacuum consumable arc-melting to form a $64 \mathrm{~mm}$ diameter cylinder which was then electric-discharge machined to the rods with $6.8 \mathrm{~mm}$ diameter and 25 or $45 \mathrm{~mm}$ length. After being ground with $80 \#$ to $1000 \#$ sandpaper and cleaned in an ultrasonic acetone bath, each sample rod was then dried and put into a special self-made ceramic crucible of $7 \mathrm{~mm}$ internal diameter and $90 \mathrm{~mm}$ length.

High vacuum of $2.0 \times 10^{-3} \mathrm{~Pa}$ was achieved before heating. When the temperature was raised to $1273 \mathrm{~K}$, argon with purity of $99.999 \%$ was then filled until the pressure reached $5.0 \times 10^{4}$ $\mathrm{Pa}$ to protect the alloying elements from oxidation or volatilizing. The temperature was kept for $5 \mathrm{~min}$ at $2323 \mathrm{~K}$ so that the alloy was entirely overheated. Then the crucible was withdrawn into the liquid Ga-In-Sn pool with a constant rate of $100 \mu \mathrm{m} / \mathrm{s}$. The specimen was later cut both horizontally and vertically and polished for metallurgical observation.

The heat-treatment was performed in a self-made ultrahigh temperature high vacuum heat-treatment furnace. Firstly, the directionally solidified specimens were placed in the center of the furnace with some sponge $\mathrm{Ti}$ to absorb any residual oxygen and to prevent oxidation of the specimen during the long-time heat-treatment. The heating process started when the vacuum reached $1.0 \times 10^{-3} \mathrm{~Pa}$ and the heating rate was controlled at $14 \mathrm{~K} / \mathrm{min}$. When the temperature reached $1273 \mathrm{~K}$, the vacuum pumping was stopped and the furnace was then filled with high purity argon (99.999\%). When the temperature in the furnace chamber reached the set value, the specimens were kept for the set period of time and then furnace-cooled. For the HT2 treatment, the DS specimens were firstly homogenized at $1623 \mathrm{~K}$ for $50 \mathrm{~h}$ and then at 1723 $\mathrm{K}$ for $50 \mathrm{~h}$ and finally aged at $1373 \mathrm{~K}$ for $50 \mathrm{~h}$. For the HT1 treatment, the DS specimens were solely homogenized at 1723 $\mathrm{K}$ for $50 \mathrm{~h}$.

X-ray diffraction (XRD, Panalytical X'pert Pro) analysis was used to determine the phases of the specimens. A scanning electron microscope (SEM, TESCAN VEGA-LMH) equipped with an energy dispersive spectroscopy (EDS, Inca $\mathrm{X}$-sight) was used to observe the microstructure and to analyze the composition.

The single-edge notched bending specimens for roomtemperature fracture toughness testing were electric-discharge machined from both the DS and DS+HT2 specimens with dimensions of $2.5 \mathrm{~mm} \times 5 \mathrm{~mm} \times 30 \mathrm{~mm}$. The notch was perpendicular to the growth direction of the directional solidification. Fig. 1 shows the shape and size of the specimens for tensile testing. The tensile axis was parallel to the growth direction of the directional solidification. Both bending and tensile tests were carried out in Instron 5567 electronic universal mechanical testing machine.

\section{Results and Discussion}

\subsection{Phase constituents}

Fig. 2 shows XRD patterns of the alloy in DS, HT1 and HT2 states. It can be seen that the alloy is comprised of two phases of $\mathrm{Nbss}$ and $\gamma$ - $(\mathrm{Nb}, X)_{5} \mathrm{Si}_{3}$ (Nbss represents niobium solid solution and $X$ represents Ti, Hf and $\mathrm{Cr}$ elements). The $\gamma$-(Nb, $X)_{5} \mathrm{Si}_{3}$ has the hP16 type hexagonal structure ${ }^{[13]}$ as the $\mathrm{Mn}_{5} \mathrm{Si}_{3}$. J. Geng et al. ${ }^{[14]}$ and K. Zelenitsas et al. ${ }^{[15]}$ reported that allotropic transformation like $\gamma$ - $(\mathrm{Nb}, X)_{5} \mathrm{Si}_{3} \rightarrow \beta$ - $(\mathrm{Nb}, X)_{5} \mathrm{Si}_{3}$ could happen in the process of high temperature heat treatment. However, after the heat-treatments of HT2 and HT1, the constituent phases of the alloys do not change but only the number of the diffraction peaks, especially those near the main diffraction peak of $\gamma$ - $(\mathrm{Nb}, X)_{5} \mathrm{Si}_{3}$ decreases. The unchanged $\gamma$ - $(\mathrm{Nb}, X)_{5} \mathrm{Si}_{3}$ indicates that this phase is fairly stable in such high temperature environment, which is the result of multi-element alloying. Moreover, the addition of $\mathrm{Hf}$ element can promote the formation of $\gamma$-( $\mathrm{Nb}, X)_{5} \mathrm{Si}_{3}$ phase and improve its stability. The weakening of the diffraction peaks of $\gamma-(\mathrm{Nb}, X)_{5} \mathrm{Si}_{3}$ might be caused by the disintegration of these large-size primary silicides after heat treatments (It will be confirmed by SEM microstructure analysis later). It should also be noted that the half peak width of the main peak of Nbss becomes smaller after both HT1 and HT2 treatments which means that the Nbss grain size becomes larger.

2.2 Microstructure evolution upon homogenizing treatment

Fig. 3 shows the microstructures of steady-state zone of the

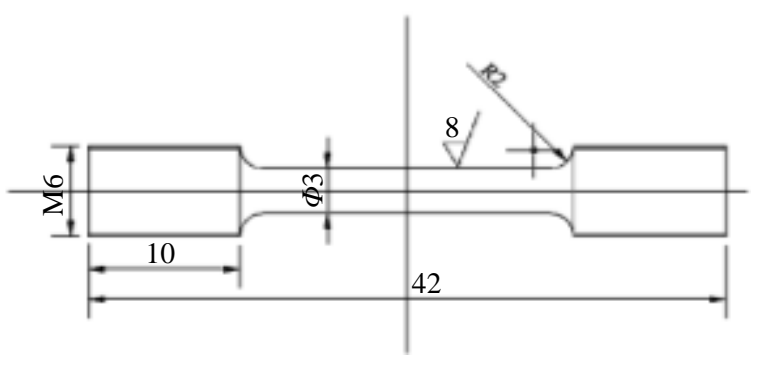

Fig. 1 Shape and size of the specimens for tensile testing

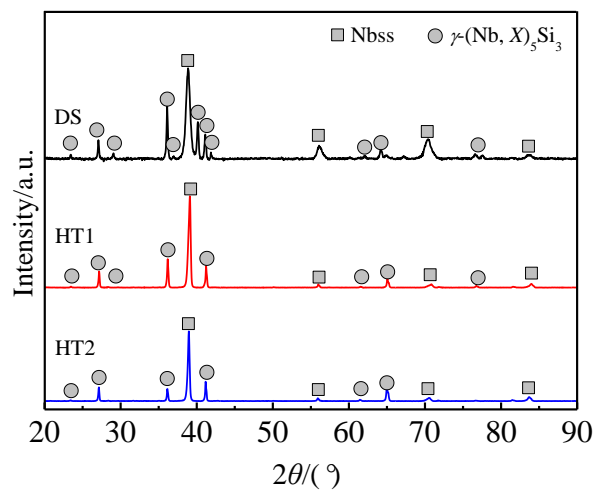

Fig. 2 XRD patterns of the alloys in DS, HT1 and HT2 states 
alloy integrally directionally solidified at $100 \mu \mathrm{m} / \mathrm{s}$. It is obvious that the microstructure of all three states consists of primary $(\mathrm{Nb}, X)_{5} \mathrm{Si}_{3}$ and $(\mathrm{Nb}, X)_{5} \mathrm{Si}_{3}+\mathrm{Nbss}$ eutectic cells. It can be seen from the microstructure of the longitudinal sections of the specimens that primary $(\mathrm{Nb}, X)_{5} \mathrm{Si}_{3}$ mainly exists in the form of long strips with dendritic side-branches somewhere and occasionally appears in network structure. The growing direction of primary $(\mathrm{Nb}, X)_{5} \mathrm{Si}_{3}$ is overall consistent with that of $(\mathrm{Nb}$, $X)_{5} \mathrm{Si}_{3}+\mathrm{Nbss}$ eutectic cells which goes almost opposite to the withdrawing direction. After these two kinds of heat- treatments, the distribution of silicides becomes more uniform and most of the network structure has been coarsened and grown into compact slices with larger size. Moreover, $(\mathrm{Nb}, X)_{5} \mathrm{Si}_{3}$ slices are more separately distributed with bigger lamellar spacing.

While for the cross-sectional microstructure, it can be seen that the eutectic cells in the DS specimens locate closely by one and another, where $(\mathrm{Nb}, X)_{5} \mathrm{Si}_{3}$ slices and Nbss slices are aligned parallel to each other (Fig.3b). Some hexagonal primary $(\mathrm{Nb}, X)_{5} \mathrm{Si}_{3}$ blocks can be seen in the center of the eutectic cells and the cell boundaries are clear (pointed out by dotted lines in Fig.3b). After the high temperature heat treatments, the majority of the microstructure has been coarsened. According to the EDS analysis results of $\mathrm{Si}$ contents in Nbss before and after heat-treatments (Table 1), it can be seen that the $\mathrm{Si}$ concentration in Nbss phase decreases after two kinds of heat-treatments, which directly leads to the increase in the amount of silicides. The original small-size silicide slices in the eutectic cells of directionally solidified specimens change their morphology to rod- and sphere-like particulates with more homogenized distribution. Another change is that the size of the central primary silicide blocks declines because they decompose into smaller blocks during the heat-treatment (Fig.3d and 3f). The silicide blocks become round with vague boundaries rather than the sharp-edged before the heat treatment. Moreover, the previous boundary area between the eutectic cells in the DS micro- structure disappears and the amount of typical lamellar eutectics decreases after the heat treatment while a more continual and nude Nbss matrix is obtained. According to the EDS analysis results, the boundary area between eutectic cells is with high Ti concentration (26.9 at\%). However, both HT1 and HT2 heat-treatments can remove the original boundary areas which are rich in $\mathrm{Ti}$, a relatively low-melting-point element. Prolonged heating would lead to the disappearance of both the segregation and the blurry boundaries. The homogenization treatment turns those cellular eutectic microstructure into $\gamma$ - $(\mathrm{Nb}, X)_{5} \mathrm{Si}_{3}$ particles or short fibers in Nbss matrix which are aligned orderly.

In addition, Fig.3d shows that the microstructure is also coarsened after the HT1 heat-treatment but the silicides are not dispersed as evenly as those after HT2. Furthermore, much finer silicides in Nbss matrix could be clearly observed in the SEM images (Fig.3d and 3f). The central silicide blocks start to break down into smaller ones. Among all the microstructure of these three states, the microstructure after HT2 exhibits the best homogeneity in size and distribution.

\subsection{Effects of heat-treatment on the room temperature mechanical properties}

\subsubsection{Room temperature fracture toughness}

It can be seen in Table 2 that the average room temperature fracture toughness of the directionally solidified specimens is 17.1 $\mathrm{MPa} \cdot \mathrm{m}^{1 / 2}$, which shows a great improvement over the
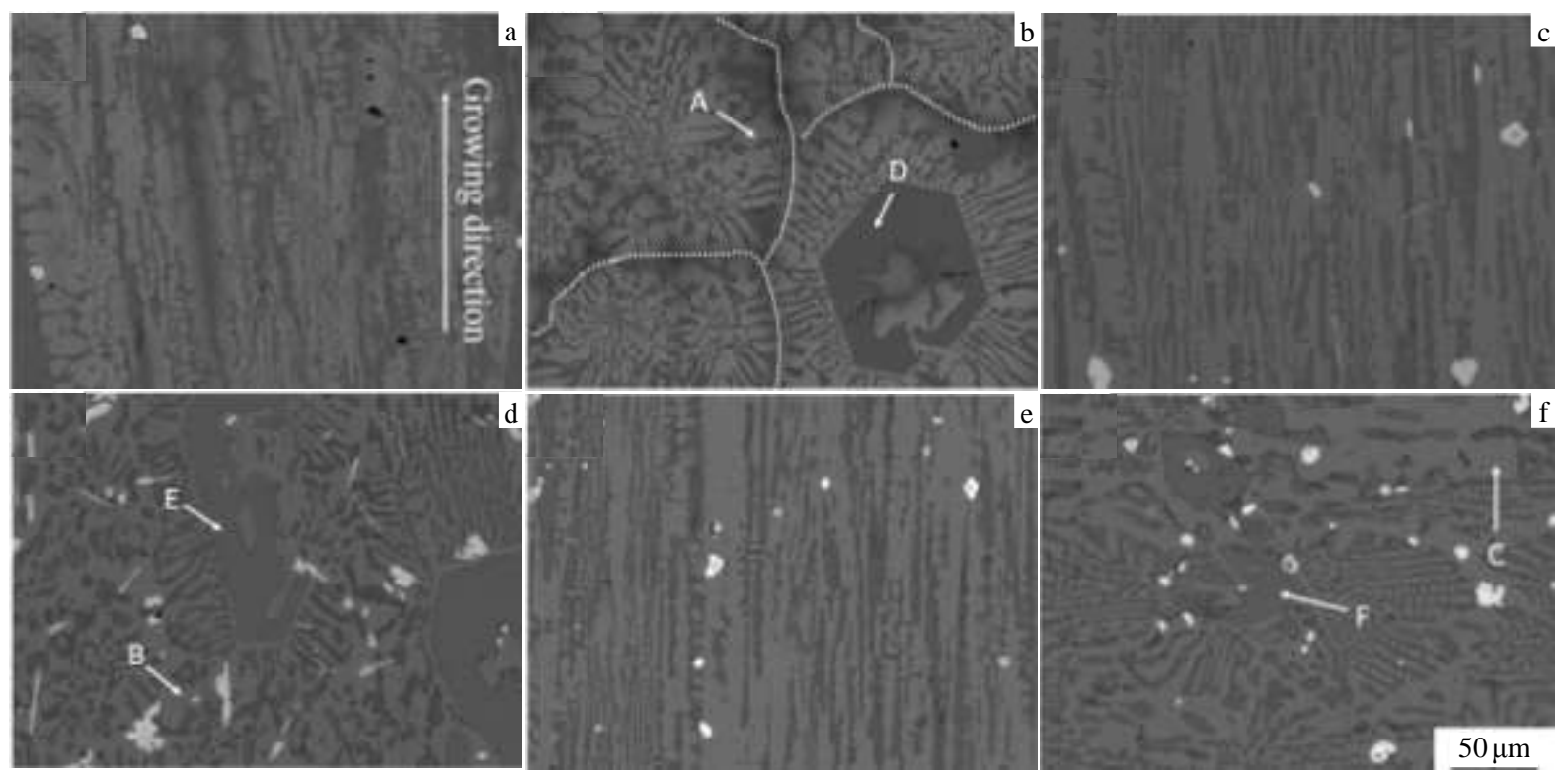

Fig. 3 BSE images of both longitudinal and transversal sections of DS (steady-state zone) (a, b), DS+HT1 (c, d) and DS + HT2 (e, f) specimens (spots $\mathrm{A}, \mathrm{B}, \mathrm{C}$ and $\mathrm{D}, \mathrm{E}, \mathrm{F}$ represent Nbss and $\gamma-(\mathrm{Nb}, X)_{5} \mathrm{Si}_{3}$ in the specimens under these three states) 
Table 1 Compositions of the Nbss and $\gamma$-(Nb, $X)_{5} \mathrm{Si}_{3}$ phases in Fig.3b, 3d, and 3f (at\%)

\begin{tabular}{ccccccc}
\hline Position & $\mathrm{Nb}$ & $\mathrm{Ti}$ & $\mathrm{Si}$ & $\mathrm{Cr}$ & $\mathrm{Hf}$ & $\mathrm{Al}$ \\
\hline Nbss-spot A(DS) & 68.0 & 19.0 & 1.8 & 6.3 & 1.4 & 3.5 \\
Nbss-spot B (HT1) & 65.9 & 20.9 & 0.7 & 7.8 & 0.4 & 4.3 \\
Nbss-spot C (HT2) & 64.9 & 21.1 & 0.6 & 8.9 & 1.0 & 3.5 \\
$\gamma-(\mathrm{Nb}, X)_{5} \mathrm{Si}_{3^{-}}$ & 44.1 & 13.9 & 35.7 & 0.4 & 3.3 & 2.6 \\
$\begin{array}{c}\text { spot D (DS) } \\
\gamma-(\mathrm{Nb}, X)_{5} \mathrm{Si}_{3^{-}}\end{array}$ & 39.8 & 18.9 & 34.7 & 1.0 & 2.8 & 2.8 \\
$\begin{array}{c}\text { spot E }(\mathrm{HT} 1) \\
\gamma-(\mathrm{Nb}, X)_{5} \mathrm{Si}_{3^{-}}\end{array}$ & 37.6 & 18.1 & 36.5 & 0.8 & 4.2 & 2.8 \\
\hline spot F (HT2) & & & & & & \\
\hline
\end{tabular}

arc-melted state. Fig.4a shows the load-displacement relationship curves of the three-point bending specimens of DS state, from which we can see that the maximum bending load has been increased up to $274.8 \mathrm{~N}$ with an increase of $24 \%$ over that of arc-melting state ${ }^{[7]}$. After the load reaches its maximum value, it goes through a sharp decline in the graph, which illustrates that the fracture of the DS state alloy is in a typical brittle fracture mode.

Fig.4b displays the relationship between load and displacement of DS+HT2 specimens. Compared with the curves of the specimens before heat treatment (Fig.4a), the curves of the specimens after heat treatment begin with almost straight lines before they reach their peaks, which indicate their better elastic deformation. As can be apparently seen in Table 2, among the three sets of specimens, the largest fracture toughness could reach as high as $20.7 \mathrm{MPa} \cdot \mathrm{m}^{1 / 2}$ while the average value is $19.2 \mathrm{MPa} \cdot \mathrm{m}^{1 / 2}$, indicating approximately $12.3 \%$ increase over the DS state. Afterwards, the load declines with a little plastic deformation.

\subsubsection{Room temperature tensile strength}

According to Table 2, the average tensile strength of the directionally solidified specimens reaches $682.5 \mathrm{MPa}$, showing a significant increase over that of the arc-melted state. Fig.5 presents the load-displacement curves of the tensile testing of directionally solidified specimens. It can be found in the graph that before reaching their maximum load value, all the three sets of the curves have been going through a plastic deformation earlier. From Table 2 it can be seen that the tensile strength has been significantly improved by the heat-treatment HT2, with an increase of approximately $26.6 \%$.

\subsection{Fracture surfaces and crack propagation paths}

2.4.1 Crack and fracture analysis of specimens for the room temperature fracture toughness testing

The cracks of both specimens have been originated at their notches and then extended along the loading direction and eventually fractured. Although both cracks deflect during their propagation process, the degree of deflection of the DS specimen (Fig.6a) is slighter than that of the heat-treated one (Fig.6d). The greater deflection of the cracks may be due to the more continuous and compact ductile Nbss phases because it's more difficult for the cracks to bypass the Nbss phase. This becomes the key reason for the improvement of the room temperature fracture toughness after heat treatment HT2.

Table 2 Room temperature fracture toughness and tensile strength of DS and DS+HT2 specimens

\begin{tabular}{|c|c|c|c|c|c|c|}
\hline Sample condition & $K_{\mathrm{Q}} / \mathrm{MPa} \cdot \mathrm{m}^{1 / 2}$ & $\begin{array}{c}\text { Average } \\
K_{\mathrm{Q}} / \mathrm{MPa} \cdot \mathrm{m}^{1 / 2} \\
\end{array}$ & $\begin{array}{c}\text { Tensile } \\
\text { strength/MPa }\end{array}$ & $\begin{array}{c}\text { Average tensile } \\
\text { strength/MPa }\end{array}$ & $\begin{array}{c}\text { Young's } \\
\text { module/GPa }\end{array}$ & $\begin{array}{c}\text { Average Young's } \\
\text { module/GPa }\end{array}$ \\
\hline \multirow{3}{*}{ DS } & 16.8 & & 530.0 & & 31.7 & \\
\hline & 17.6 & 17.1 & 575.9 & 682.5 & 61.8 & 55.2 \\
\hline & 16.9 & & 941.6 & & 71.9 & \\
\hline \multirow{3}{*}{$\mathrm{DS}+\mathrm{HT} 2$} & 16.4 & & 933.2 & & 65.8 & \\
\hline & 20.7 & 19.2 & 816.3 & 863.8 & 65.8 & 66.4 \\
\hline & 20.5 & & 841.8 & & 67.7 & \\
\hline
\end{tabular}
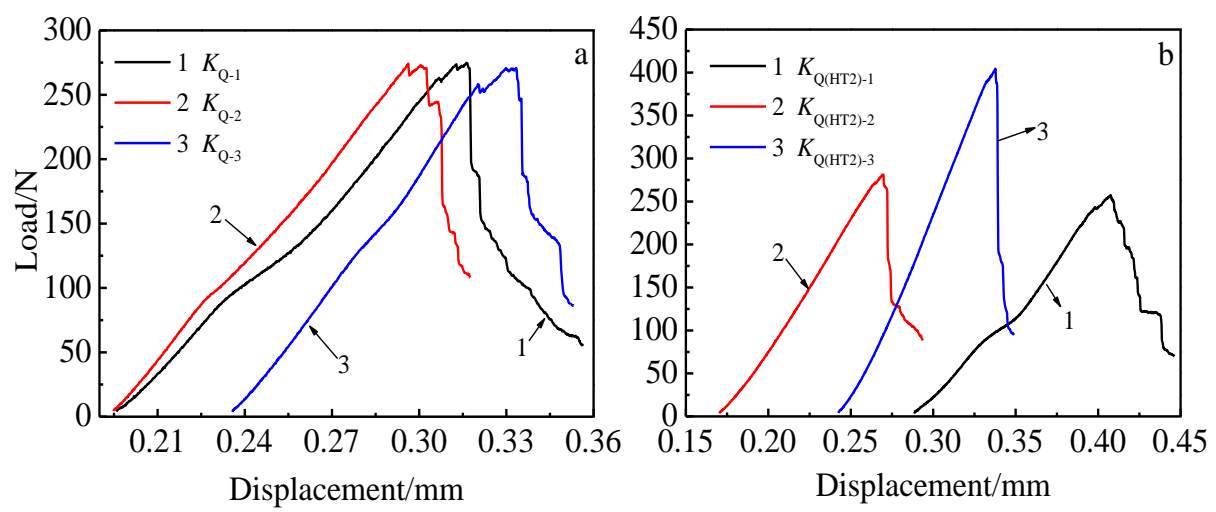

Fig. 4 Load-displacement curves of three-point bending specimens in DS (a) and DS+HT2 (b) states 

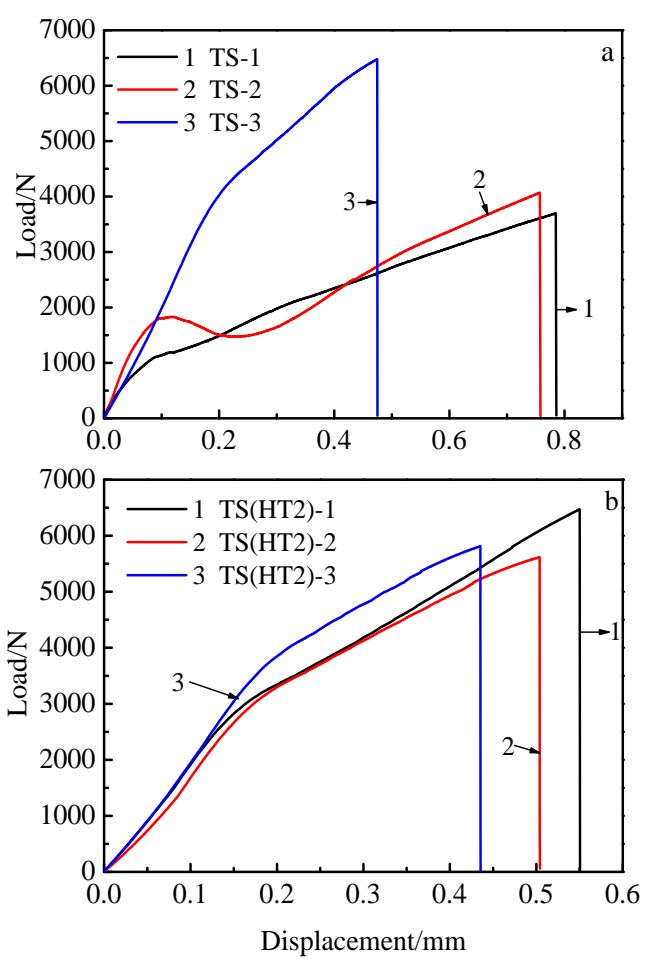

Fig. 5 Load-displacement curves in room temperature tensile test for DS (a) and DS+HT2 (b) specimens

The fracture surfaces of both specimens are generally uneven and undulating, which indicates that plastic deformation must have occurred during the fracture process (Fig.6b and 6e). Basically, there is no significant difference between the fractography of the specimens of these two states, but the pits are more obvious in the middle of the fracture surface of the DS specimen. The fracture structure of the DS specimen (Fig.6c) is finer than that of heat-treated ones (Fig.6f). On the fracture surfaces of the DS specimen, tearing ridges can be clearly observed which radiate out from the center to the surroundings. The central bright tearing ridges appear as petal-like protrusions (Fig.6c). While on the fracture surface of the heat-treated specimen, the microstructure seems much coarser, there are obvious dimples present and the size of the tearing ridges is significantly increased. Some second phase particles can be found in many places (Fig.6f) in the fracture surface of HT2 treated specimen which means the fracture process has been hindered by the second phase particles.

2.4.2 Room temperature tensile testing fracture surfaces

Fig.7 shows the fractography of the room temperature tensile testing specimens in both DS and DS+HT2 states. It is obvious that there is apparent deformation in the fracture surface of the specimen without heat treatment (Fig.7a), and a relatively large section of ridges could be found on this fracture surface (Fig.7b). Although similar ridges could also be found on the surface of heat-treated specimens (Fig.7c), the fluctuation is more frequent than that in the former. In the
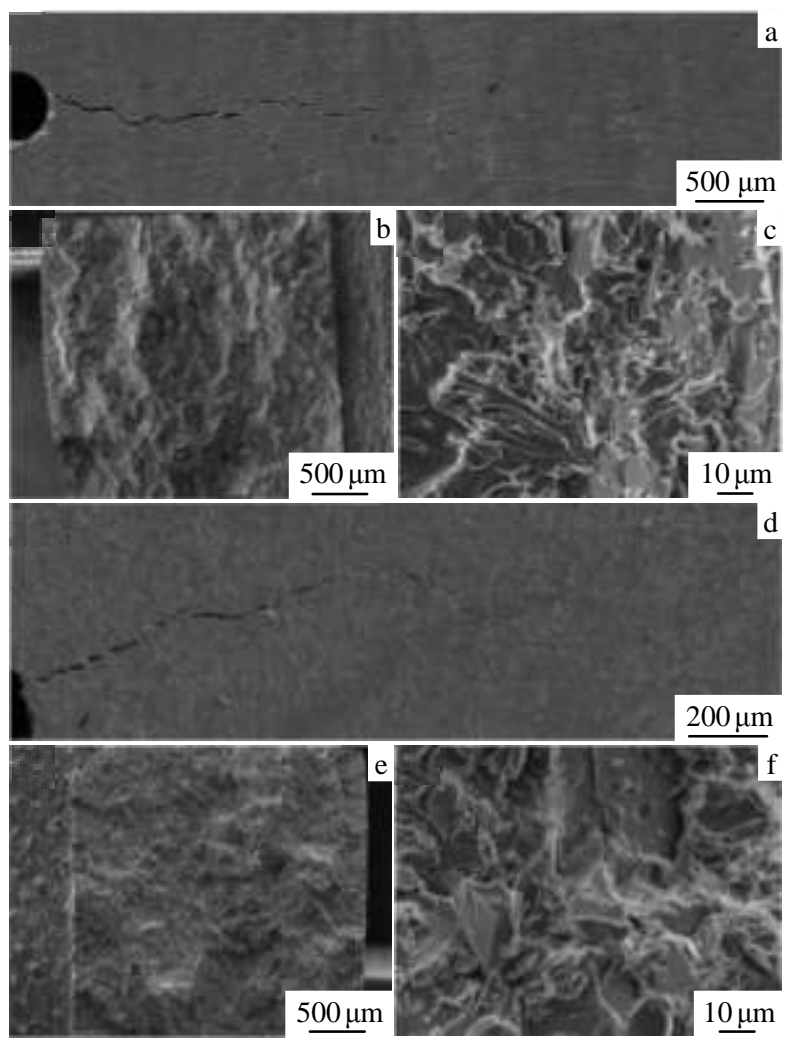

Fig. 6 Crack propagation paths and fracture surface morphologies of DS $(\mathrm{a} \sim \mathrm{c})$ and DS + HT2 (d f) specimens

fracture surfaces of both states, typical cleavage steps (indicated with arrows in Fig.7b and 7d) are observed. Moreover, the presence of second phase particles is also found in the fracture surface (indicated with white circles in Fig.7b and Fig.7d).

The improvement of the mechanical properties after HT2 heat-treatment should be attributed to the following: Firstly, fine silicide particles precipitate in Nbss after the high

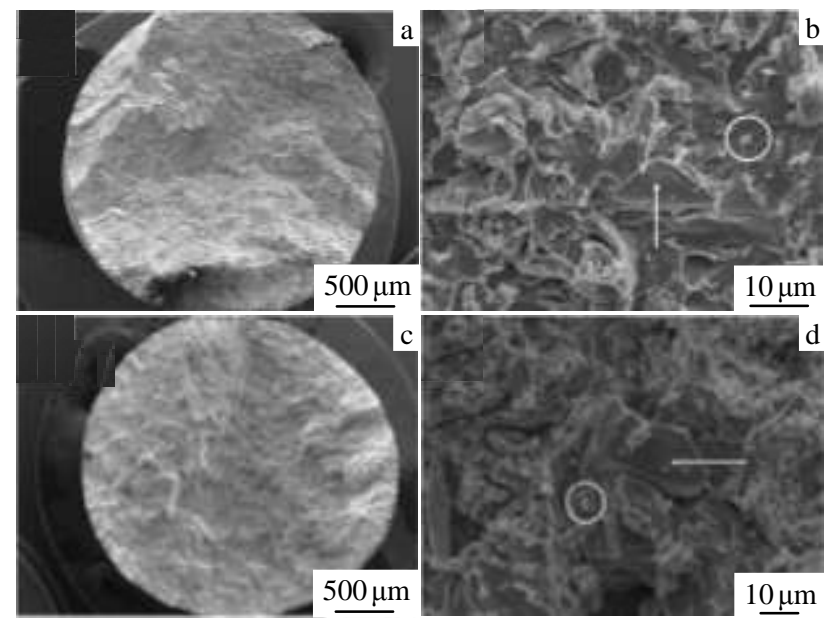

Fig. 7 SEM images of the fracture surfaces of DS (a, b) and DS+ HT2 (c, d) specimens after tensile tests 
temperature heat-treatment (Fig.3d and 3f). The alloy has been therefore further dispersion-strengthened, leading to an increase in the mechanical properties. Secondly, the big silicide blocks with sharp edges in DS specimens have turned into smaller ones with smooth and round edges (Fig.3f) and segregation has been eliminated (Fig.3d and $3 \mathrm{f}$ ) after the heat-treatment, so that crack propagation process would be sluggish. Finally, Nbss becomes more continuous and their width increases after HT2 treatment, which will make it more difficult for the crack to expand. Sometimes, the cracks have to go across the Nbss directly for expansion.

\section{Conclusions}

1) After HT1 and HT2 heat treatment, the size of the primary silicides decreases. The original vague boundaries between the eutectic cells disappear because of the elimination of the segregation after heat-treatment.

2) The HT2 heat-treatment obviously improves both the room temperature fracture toughness and tensile strength by precipitating fine silicide particles, turning primary large-size silicide blocks into smaller ones with round and smooth edge and the formation of more continuous Nbss matrix.

\section{References}

1 Kang Y W, Qu S Y, Song J X et al. Acta Metallurgica Sinica[J], 2008, 44(5): 593

2 Guo X P, Guo H S, Yao C F et al. International Journal of
Modern Physics B[J], 2009, 23(6-7): 1093

3 Bewlay B P, Jackson M R, Zhao J C et al. MRS Bulletin[J], 2003, 28(9): 646

4 Bewlay B P, Jackson M R, Zhao J C et al. Metallurgical and Materials Transactions A[J], 2003, 34(10): 2043

5 Guo B H, Guo X P. Materials Science and Technology[J], Doi:10.1179/1743284714Y.0000000511

6 Guo H S, Guo X P, Yao C F. Rare Metal Materials and Engineering[J], 2009, 38(1): 26

7 Guo H S, Guo X P, Zhao H L. Rare Metal Materials and Engineering[J], 2014, 43(4): 1019 (in Chinese)

8 Guo B H, Guo X P. Rare Metal Materials and Engineering $[\mathrm{J}]$, 2013, 42(7): 1390 (in Chinese)

9 Huang Q, Guo X P, Kang Y W et al. Progress in Natural Science: Materials International[J], 2011, 21(2): 146

10 Guo H S, Guo X P. Scripta Materialia[J], 2011, 64(7): 637

11 Liu W, Fu Y M, Sha J B. Progress in Natural Science: Materials International $[\mathrm{J}], 2013,23(1): 55$

$12 \mathrm{Su}$ L F, Jia L N, Zhang $\mathrm{H}$ et al. Materials Science and Engineering $A[\mathrm{~J}], 2013,560: 672$

13 Qu S Y, Han Y F, Kang Y W. Science in China, Series E: Technological Sciences[J], 2009, 52(1): 37

14 Geng J, Tsakiropoulos P, Shao G. Intermetallics[J], 2006, 14(3): 227

15 Zelenitsas K, Tsakiropoulos P. Intermetallics[J], 2005, 13(10): 1079

\title{
热处理对定向凝固 Nb-Ti-Si 基合金组织及力学性能的影响
}

\author{
严俊杰, 郭喜平 \\ (西北工业大学 凝固技术国家重点实验室, 陕西 西安 710072)
}

\begin{abstract}
摘 要: 在熔体温度为 $2323 \mathrm{~K}$, 抽拉速率为 $100 \mu \mathrm{m} / \mathrm{s}$ 的条件下对 $\mathrm{Nb}-\mathrm{Ti}-\mathrm{Si}$ 基超高温合金进行了有坩埚整体定向凝固 (DS), 然后对定向 凝固试样进行了 2 种不同工艺的热处理：即 $1723 \mathrm{~K} / 50 \mathrm{~h}$ 高温均匀化处理 (HT1) 和 $1623 \mathrm{~K} / 50 \mathrm{~h}+1723 \mathrm{~K} / 50 \mathrm{~h}+1373 \mathrm{~K} / 50 \mathrm{~h}$ 复合热处理 (HT2)。采用 XRD, SEM 和 EDS 等分析手段研究热处理对定向凝固合金微观组织及其力学性能的影响。结果表明, 热处理后合金中大 尺寸初生硅化物的体积分数下降, 2 种方式的热处理均能有效减轻甚至消除合金中的成分偏析。热处理后原 $\mathrm{DS}$ 试样中 $\mathrm{Nbss}+(\mathrm{Nb}, X)_{5} \mathrm{Si}_{3}$ 共晶胞的边界完全消失。相比 HT1 处理, HT2 处理后试样中硅化物的分布更加均匀。与 DS 试样相比, 经 HT2 处理后试样的室温断裂 韧性值增加了 $12.3 \%$ (约 $19.2 \mathrm{MPa} \cdot \mathrm{m}^{1 / 2}$ ), 且其抗拉伸强度增加了 $26.6 \%$ (最大值达到 $933.2 \mathrm{MPa}$ )。力学性能的改善主要归因于热处理后 组织中 $(\mathrm{Nb}, X)_{5} \mathrm{Si}_{3}$ 颗粒弥散分布以及韧性 $\mathrm{Nbss}$ 相的形状、尺寸及含量均发生变化。
\end{abstract}

关键词: Nb-Ti-Si 基超高温合金; 整体定向凝固; 热处理；断裂㓞性；拉伸强度

作者简介: 严俊杰, 男, 1988 年生, 硕士生, 西北工业大学凝固技术国家重点实验室, 陕西 西安 710072, 电话: 029-88494873, E-mail: xpguo@nwpu.edu.cn 